\title{
A Comparative Study of the Phenomenon of Pronominalisation in French and in Igbo
}

\author{
N. O. Offor
}

\begin{abstract}
The main objective of the generative theory particularly the transformational generative grammar is to present a grammar that will serve as a mechanism for explaining the syntactic phenomenon in all human languages while also taking into cognisance their areas of similarities as well as aspects of divergences. It is in this line of thought that this paper examined the transformational rules that apply to the syntactic phenomenon of pronominalisation in the French and Igbo languages with focus more on that of Igbo language. It specifically studied syntactic operations involved in the process of pronominalisation in the two languages in order to highlight the aspects that are universal to the two languages as well as their areas of divergences. It also noted certain syntactic traits peculiar to each language, more so as both languages belong to two different language families. The study therefore revealed that the phenomenon of pronominalisation in Igbo involves the replacement of certain categories of grammatical elements but does not necessarily entail movement of these elements as in the case of French language where it involves both replacement and movement particularly in the case of personal pronoun complements.
\end{abstract}

Index Terms-Comparative study, phenomenon, pronominalisation, pronoun/pronominal.

\section{INTRODUCTION}

The phenomenon of pronominalisation is inherent in human languages as pronominals are syntactic properties that are universal to human languages. This paper therefore examines the phenomenon of pronominalisation as it applies in Igbo in comparison to French. The aim of this study is to afford a better understanding of this phenomenon in the aforementioned languages by analysing the traits of this syntactic operation in these two languages. However, before proceeding, there is need for a brief overview of the Igbo language and French language.

Igbo language is one of the major native languages being spoken in Nigeria. According to Greenberg's classification of African languages as cited by Uwalaka, it belongs to the "kwa" languages of the Niger-Congo language stock [1]. There are many dialects in Igbo language; however, in this work, the central Igbo is used. The central Igbo is the variety commonly accepted by the Igbo community at large. This variety is also called the standard Igbo. The standard Igbo is a codified variety which is drawn dominantly from

Manuscript received April 6, 2015; revised August 15, 2015. This work was supported in part by the Nigerian Tertiary Education Trust fund (TETFund) under TETFund Conference Attendance Intervention.

N. O. Offor is with the Department of French, Federal College of Education Kontagora, P.M.B 39, Kontagora, Niger state, Nigeria (e-mail: onoffor@yahoo.co.uk). the Owerri, Umuahia, and Onitsha dialects [2]. The Igbos occupy the South-Eastern region of Nigeria comprising Abia, Anambra, Ebonyi, Enugu and Imo States as well as some parts of Delta and Rivers States [3].

French is one of the romance languages [4] of the italic sub-family of the Indo-European language phylum. It is the native language spoken by the people of France as well as in some parts of Belgium, Switzerland, Luxembourg and Canada. French also serves as an official language in her former African colonies and as well, as a language of communication in some countries of the world. French is also one of the internationally recognised languages used by international organisations such as United Nations Organisations. The French language as in the case of the Igbo language is of different dialectal varieties [4]. However, in this work, the standard French is used.

This study is divided into three sections. In the first section, the theoretical framework on which the analysis is based is presented. In the second part, the notion of pronominalisation is generally examined as well as its peculiar application to French language. Finally, the third part is consecrated to the analysis of the pronominalisation process in Igbo with the aim of bringing to light the particularities of this phenomenon in Igbo language in comparison to French.

\section{THEORETICAL FRAMEWORK}

In this study, the theory of transformational generative grammar is chosen to explain the phenomenon of pronominalisation in Igbo in comparison to that of the French language. The objective of the transformational generative grammar is to propose a grammar that is not limited to the description of syntactic structures but also explains syntactic phenomena in human languages.

The fundamental idea of transformational generative grammar is therefore to present a grammar that could afford the analyses of languages by studying language structures at two levels: the D-Structure and S-Structure level [5]. According to Chomsky, it is only an analysis carried out in this manner that will give room for an adequate analysis of sentence structures. He puts it thus: «seule la construction $\mathrm{du}$ niveau encore plus abstrait des transformations peut ouvrir la voie au développement d'une technique plus simple et plus adéquate d'analyse en constituants, dans des limites plus étroites» [6]. The transformational generative grammar provides us therefore with tools for explaining syntactic phenomenon which applies to the D-structure in order to transform it to the S-structure. Hence in this work, we have examined the transformational rules that apply to the phenomenon of pronominalisation in Igbo and in French. 
This way, the phenomenon is explained as it applies to each language particularly to Igbo language which is the language in focus.

\section{The NOTION OF PRONOMINALISATION}

\section{A. Pronoun}

Generally, a pronoun is defined as a variable word that could be used to replace a noun or a noun phrase. It either refers to a person or term previously mentioned within a given syntactic context. According to Grevisse cited by Oliveri, a pronoun in the large sense could represent a noun, an adjective, an idea or a clause [7]. He further presented the following examples in French to buttress his point:

Prenez ces cent écus : gardez-les avec soin.

Généreux, vous $l$ 'êtes.

S'il t'arrive malheur, tu l'auras mérité.

Je vous le répète : il faut travailler [7].

A pronoun could therefore be referred to as a syntactic element which can replace a Noun phrase [NP], an Adverbial phrase [AdvP], an Adjectival phrase [AdjP], a complementizer phrase [CP] or an inflectional phrase [IP]. A pronoun being noun substitute could assume the syntactic function of a noun which it replaces by functioning as a subject or a complement.

Pronouns are one of the syntactic elements which are universal to all languages. Affirming this fact, Benveniste stated that: «toutes les langues possèdent des pronoms» [8] $\mathrm{He}$ also acknowledged that there are different types of pronouns which include: the personal, possessive, demonstrative, indefinite pronouns etc. «... et dans toutes on les définit comme se rapportant aux mêmes catégories d'expression (pronoms personnels, démonstratifs etc.» [8]. The inventory of pronominals as well as the transformational rules that apply to their usage varies from one language to another. Pointing out these divergences, Benveniste added that «les pronoms ne constituent pas une classe unitaire, mais des espèces différentes selon le mode de langage dont ils sont les signes» [8].

Taking into cognizance that lots of works have been carried out on pronouns in French, this study therefore focuses particularly on the Igbo language. A study of the use of pronouns in the Igbo language shows that the inventory of pronominals in Igbo is not as exhaustive as that of French. Haven observed this trait in Igbo pronouns, Emenanjo defined it as «a closed class of 7 items » [9], which we have summed up in the Table I below.

\begin{tabular}{clcc}
\multicolumn{4}{c}{ TABLE I: IGBO PRONOUNS } \\
\hline Number & \multicolumn{1}{c}{ Person } & Subject & Object \\
\hline Singular & $1^{\text {st }}$ person & $\mathrm{m}$ & $\mathrm{mu}$ \\
& $2^{\text {nd }}$ person & $\mathrm{i} / \mathrm{i}$ & gị \\
& $3^{\text {rd }}$ person & o/ọ & ya \\
& Impersonal & e/a & \\
Plural & $1^{\text {st }}$ person & \multicolumn{2}{c}{ Anyi } \\
& $2^{\text {nd }}$ person & \multicolumn{2}{c}{ unu } \\
& $3^{\text {rd }}$ person & \multicolumn{2}{c}{ ha } \\
\hline
\end{tabular}

From the table, we observed that in Igbo, pronouns are sub-divided into two forms according to their functions either as subjects or objects. We also noted that the subject forms of the 2 nd and 3rd person singular pronouns as well as the impersonal form have two alternating forms which are used according to the rule of vowel harmony. This rule demands that there be harmony between vowels [i], [i], [o] and [o] of the $2^{\text {nd }}$ and $3^{\text {rd }}$ person subject pronoun and the verb in the sentence. The form of these pronouns in a given sentence is therefore determined by the vocalic features of the vowels in the verb used. If the vowel of the verb is "pharyngealised" [10], the subject pronoun will also be pharyngealised, the same thing applies when it is "nonpharyngealised" [10] as observed in examples (1) and (2) below: I zưrụ akwụkwọ.

Tu as volé.

O zuru ohi.

Tu as acheté un livre.

Elle/Il a volé.

Ọ zụrụ akwụkwọ. Il/Elle a acheté un livre.

In sentence (1a) the personal pronoun " $i$ " is in harmony with the vowels of the verb "zuru". The same applies to sentence (1b) in which " $i$ ", is also in harmony with "zurụ". This harmony also exists between " $o$ " and "zuru" in sentence (2a) as well as with " $Q$ " and "zuru" in sentence (2b). We also observed that in the plural form, the same word is used for the subject and object pronouns in Igbo.

This work is particularly interested in the phenomenon of pronominalisation as it applies to the subject and object pronouns; hence, there is need for the explanation of the term, pronominalisation.

\section{B. Pronominalisation}

Pronominalisation is a syntactic process in which a referring expression (R-expression) $N P$ is replaced by a pronominal NP. Mbah described the process of pronominalisation as being concerned with "the formation of the pronouns in the grammar of a language" [11]. He therefore defined pronominalisation as a process in which "the pronouns substitute their referential expressions" [11]. Oluikpe citing Fowler defined pronominalisation as "the process by which a pronoun is substituted for a noun phrase which is not a pronoun in the deep structure" [12].

According to Ayi-Adzimah, pronominalisation entails substitution, hence, «comprend essentiellement la substitution ou le plus souvent la reprise des éléments déjà citée. Sans modifier radicalement l'information, la substitution enrichit la production langagière par l'éviction de la répétition» [13]. This description by Ayi-Adzimah corresponds with the description of pronominalisation presented by Dubois et Dubois-Charlier: «la transformation pronominale déclenchée par la présence dans le syntagme nominal qui subit la pronominalisation d'un démonstratif dont le rôle sémantique (l'interprétation sémantique) est d'instituer une «référence» entre ce syntagme nominal et le syntagme nominal d'une phrase antérieure ou un syntagme nominal présupposé» [14].

Riegel cited by Ayi-Adzimah also views pronominalisation as an operation of substitution. He therefore defined pronominalisation as an opération of substitution that «consiste à remplacer un élément $\mathrm{A}$ d'une construction donnée (par exemple d'une phrase ou d'un groupe syntaxique) par un élément B sans que la phrase 
devienne agrammaticale» [13]. Thus, pronominalisation entails substitution of R-expression by Pronominals without altering the meaning of the sentence structure as presented in deep structure. Example:

- Où as-tu perdu la clé?

- Je l'ai perdue sur la route.

Sentences (3) and (4) show example of the case of pronominalisation where the R-expression NP "la cle" is substituted by the pronominal NP " $l$ " " while retaining its original contextual meaning as presented in sentence (3).

From the generative point of view, pronominalisation is a type of transformation in which the constituents of a sentence in the D-structure is replaced by the pronoun in the surface structure. This is why Dubois and Dubois-Charlier referred to pronominalisation as pronominal transformation «la transformation pronominale» [14]. Pronominalisation could be referred to as the process of replacing words or group of words by pronouns. It implies the replacement or the substitution of a sentence constituent by a pronoun. In other words, pronominalisation is the substitution of a word or a group of words using a pronoun. In French, pronominalisation helps to easily define a syntactic unit. Example:

\section{- Jacques pose des questions aux étrangers.}

In sentence (5a), there are three R-expressions NP which are in italics. The first R-expression NP "Jacque" is the subject, the second R-expression NP "des question" is the first object, and finally the third R-expression NP "aux étrangers" is the second object. Structure (5a) can be replaced with the pronouns that correspond to each lexical NP defined in sentence ( $5 b)$ here below:

$$
\text { - Il pose } e n_{\mathrm{i}} l e u r_{\mathrm{j}} \text {. }
$$

But the structure of (5b) is not accepted in French because the order of placement of pronoun complements is different from that of the R-expression object NP; hence the need for movement after replacement in order to obtain an acceptable sentence order.

$$
\text { - } \underline{\text { Il }} \underline{\text { leur }} \underline{\mathrm{en}}_{\mathrm{i}} \text { pose } \mathrm{t}_{\mathrm{i}} \mathrm{t}_{\mathrm{j}}
$$

The pronoun complements "en" and "leur" are therefore moved from their post-verbal position to be placed before the verb "pose" according to the rule guiding the order of placement of pronoun complements in French. This process of replacement of R-expression NPs by pronoun in the SStructure is what is called pronominalisation. Let's now find out how the phenomenon of pronominalisation functions in Igbo.

\section{THE PHENOMENON OF PRONOMINALISATION IN IGBO}

\section{A. Pronominalisation of Subject R-Expression NPs}

In Igbo language as in most natural languages, pronominals that function as subject are referred to as subject pronouns and are usually assigned the nominative case in sentences. Therefore, they often precede the verb given that they are subject NPs. However in Igbo, at times the subject pronoun of the $1^{\text {st }}$ person singular «m» (I) and $3^{\text {rd }}$ person plural «ha» (they) could be placed after the verb in the sentence. When this happens, the vowel prefix «e/a» is added to the verb in accordance with the rules of vowel harmony. Examples:

- $M$ hụrụ ya.

Je voir (Passé) le/la.

Je le/la ai vu.

- $\mathrm{t}_{\mathrm{i}}$ Ahụrụ $\boldsymbol{m}_{\mathrm{i}}$ ya.

(Préfixe) voir (Passé) je le/la.

Je le/la ai vu.

- Ha jere ụlọ ụka.

Ils/Elles aller (Passé) église.

Ils/Elles sont allés à l'église.

- $\mathrm{t}_{\mathrm{j}}$ Ejere $\boldsymbol{h} \boldsymbol{a}_{\mathrm{j}}$ ụlọ ụka.

(Préfixe) aller (Passé) ils/elles église.

Ils/Elles sont allés à l'église.

From sentences (6) and (7), the movement of subject pronominal NP ' $m$ ' and 'ha' is observed. The trace of this movement is indicated by indices in sentences $(6 b)$ and $(7 b)$ marking their position in the deep structure. There is also the insertion of prefixes «a» and «e» in structures (6b) and (7b). Subject pronouns replace only R-expression NPs that function as subject. Examples:

- Ifeoma na Chinyere nọ n'ezi. Ifeoma et Chinyere sont dans la cour.

- Ha nọ n'ezi. Elles sont dans la cour.

- Mu na Ebere na-aza ụlọ. Ebere et moi balayons la maison.

- Anyi na-aza ụlọ. Nous balayons la maison.

- Nwa gi kwara akwa ofụma. Ton fils a bien cousu le tissu.

- $\boldsymbol{O}$ kwara akwa ofụma. Il a bien cousu le tissu.

- Oche a dị elu. Cette chaise est grande

- $\boldsymbol{O}$ di elu.

Elle est grande.

The subject R-expression NPs and the subject pronouns NPs that replace them are in bold typeface. We also observed that the gender difference marked by the $3^{\text {rd }}$ person singular and plural in French is neutralized in Igbo. Hence, we could say that gender agreement does not apply to pronominals in Igbo. However, it is also important to note that in both languages, it is only the $3^{\text {rd }}$ person singular and plural that are used for the pronominalisation of subject Rexpression NPs that are either animate or inanimate as observed in sentences (10) and (11). But other subject pronouns refer only to R-expression NPs that are animates.

It is also important to note that pronominals could equally function as expletive pronouns particularly if they are placed in the subject position of verbs referred to as verbs of raising, such as the following verbs enumerated by Mbah: $d i$ 
(ka) - semble/parait, nwe ike- pouvoir être, tosiri/kwesiri supposelfaut etc. (GB Syntaxe170). Examples:

- $\boldsymbol{O}$ tosiri [Ndidi iga Onitsha echi]. Il suppose Ndidi aller Onitsha demain.

Il suppose [que Ndidi va à Onitsha demain].

This type of pronoun is not assigned any semantic value rather syntactic values are accorded to it in the sentence.

\section{B. Pronominalisation of Object R-Expression NPs}

The object pronouns play lots of roles in Igbo particularly as pronoun complements. In fact, for this form of pronominals, it is their grammatical function in a given sentence that determines their syntactic nature. In this section, the roles of direct and indirect object pronouns in the realisation of the process of pronominalisation in Igbo are being examined. The case of double pronominalisation is also considered.

\section{1) Pronominalisation of direct object r-expression NPS}

In Igbo, the object pronoun could function as a direct object complement by replacing an R-referential NP that occupies the position of a direct object complement as in the following sentences.

- M tufuru igodo $_{\mathrm{i}}$. J'ai perdu la clé . $_{\text {. }}$

- M tufuru $y a_{\mathrm{i}}$. Je $l_{\mathrm{i}}$ 'ai perdue $\mathrm{t}_{\mathrm{i}}$.

- Obioma na-ede $\boldsymbol{a} \boldsymbol{k} \boldsymbol{w} \boldsymbol{a}_{\mathrm{i}}$. Obioma repasse les habits

- Obioma na-ede $\boldsymbol{y} \boldsymbol{a}_{\mathrm{i}}$.

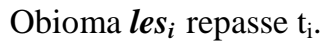

- Onye kpọtara ụmụaka ndi $\mathrm{a}_{\mathrm{i}}$ ? Qui a amené ces enfants $t_{i}$ ?

- Onye kpọtara $\boldsymbol{h a}_{\mathrm{i}}$ ? Qui les $s_{\mathrm{i}}$ a amenés?

- Gi na Chika $\mathrm{i}_{\mathrm{i}}$, unu ekeleela $\boldsymbol{m}_{\mathrm{j}}$ ? Toi et Chika, $m_{i}$ 'avez-vous salué $\mathrm{t}_{\mathrm{i}}$ ?

- Eé, anyi $i_{\mathrm{z}}$ ekeleela $\boldsymbol{g} \boldsymbol{i}_{\mathrm{k}}$.

- Oui, nous $t_{\mathrm{j}}$ 'avons salué $\mathrm{t}_{\mathrm{j}}$.

- Unu azutasiri $\boldsymbol{o g o d o}_{\mathrm{i}}$ ? Vous avez acheté des pagnes $\mathrm{t}_{\mathrm{i}}$ ?

- Eé, anyi zutara $\boldsymbol{h} \boldsymbol{a}_{\mathrm{i}}$. Oui, nous $\boldsymbol{e n} \boldsymbol{n}_{\mathrm{i}}$ avons acheté $\mathrm{t}_{\mathrm{i}}$.

The direct object pronouns are in bold typeface in the two languages. In contrast to French, gender agreement does not exist between the $3^{\text {rd }}$ person singular direct object pronoun and the direct object R-expression NP that it replaces in Igbo as observed in sentences (13a) and (13b). Moreover in Igbo, pronominalisation does not induce verbal agreement in the perfect tense particularly between the object pronoun and the verb in the past participle. This is because pronominalisation in Igbo does not involve the movement of object pronouns from the post-verbal position to that of the pre-verbal position. Hence the pronominalisation of ' la clé' in French as observed in sentences (13a) and (13b) triggers the agreement between "l'(la)" and the verb "perdue" which is in the past participle.

In Igbo as also observed in sentences (13b) to (17b), the direct object pronouns replace the direct object R-expression NPs, while retaining the post-verbal position of their coreferentials in the D-structure. But in French, the object pronouns do not retain the post-verbal position of the coreferential which they replace rather they move to the preverbal position. The trace of the movement is demonstrated in sentences (13b) to $(17 b)$ by indices. Sentences (17a) and (17b) show that pronoun 'en' does not exist in Igbo. But this pronoun exists in French and is used in the replacement of object NPs that are preceded by partitive articles [du, de la, de l' and des] or preposition "de".

\section{2) Pronominalisation of indirect object r-expression NPs}

Object pronouns are used to replace indirect object complements.

Examples:

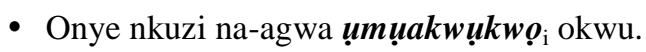
Le professeur parle [aux étudiants $]_{\mathrm{i}}$

- Onye nkuzi na-agwa $\boldsymbol{h a}_{\mathrm{i}}$ okwu. Le professeur leur $_{\text {i }}$ parle $t_{i}$.

- Ụmụaka ndi a ana-erubere $[\text { nne ha }]_{\mathrm{i}}$ isi? Ces enfants obéissent à leur mère $\boldsymbol{~}_{\mathrm{i}}$ ?

- Eē, umuaka ndi a anaghi-erubere $y \boldsymbol{a}_{\mathrm{i}}$ isi. Non, ces enfants ne $l u i_{\mathrm{i}}$ obéissent pas $\mathrm{t}_{\mathrm{i}}$.

- Ana m eje [ulo uka $]_{\mathrm{i}}$ Je vais à l'église $\boldsymbol{i}_{\mathrm{i}}$.

- * Ana m eje $\mathrm{ya}_{\mathrm{i}}$. $\mathrm{J} \boldsymbol{y}_{\mathrm{i}}$ vais $\mathrm{t}_{\mathrm{i}}$.

First, note that in Igbo, the morphemes used for the indirect object pronouns are the same as those of the direct object pronouns, but in French, the words that mark the direct object pronouns are different from those of the indirect object pronouns. Secondly, we also observed from sentences (18a) and (19a) that Igbo verbs are transitive; hence, every action expressed has a direct object through which the effect of the action is transferred. This therefore shows that in Igbo, there is no sentence that has the indirect object complements [COI] without having a direct object complement COD as observed in sentences (18a) and (19a). The direct object complements 'okwu' and 'isi' are found in Igbo in the aforementioned sentences while in French, there is no such constituent in the sentences. Thirdly, we also noted that indirect object complement precedes the direct object complements in Igbo. Hence the COI 'umuakwukwo' precedes the COD 'okwu' in the sentence (18a) and the COI ' $n n e$ ha' precedes the COD 'isi' in sentence (19a).

Sentence (20b) is ungrammatical in Igbo as circumstantial complements of places are not replaced with pronouns in Igbo. Hence pronoun " $y$ " does not exist in Igbo. It is also important to note that the pronominalised Rexpression COIs in Igbo are not introduced by prepositions as they are not prepositional phrases [PP] but NPs. It could therefore be deduced that it is only R-expression NPs that are pronominalised in Igbo. Prepositional phrases [PP] are hardly pronominalised in Igbo as observed in the analyses of sentences (18a) and (19a) below:

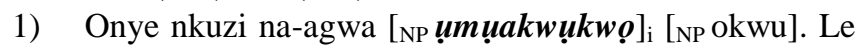
professeur parle [SPrép aux étudiants $]_{\mathrm{i}}$ 
2) Umuaka ndi a ana-erubere $\left[{ }_{\mathrm{NP}} \boldsymbol{n} \boldsymbol{n} \boldsymbol{e} \boldsymbol{h a}\right]_{\mathrm{i}}\left[{ }_{\mathrm{NP}}\right.$ isi]? Ces enfants obéissent [SPrép à leur mère $\left.{ }_{\mathrm{i}}\right]$ ?

\section{3) The case of double pronominalisation}

Double pronominalisation is said to have occurred in a sentence, when two object complements are simultaneously replaced by their corresponding pronoun complements. Example:

- Nnamdi enyela Adaugo $_{\boldsymbol{i}} \boldsymbol{e g o}_{\boldsymbol{j}}$. Nnamdi a donné [de l'argent $]_{j}$ à Adaugo . $_{\text {. }}$

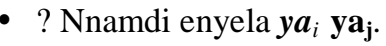
Nnamdi $\boldsymbol{l u} \boldsymbol{i}_{\mathrm{i}} \boldsymbol{e n _ { j }}$ a donné $\mathrm{t}_{\mathrm{j}} \mathrm{t}_{\mathrm{i}}$.

- Anyị tụfụrụ igodo $_{i}$ n'uzo $_{\mathrm{j}}$. Nous avons perdu la clé $\mathrm{e}_{\mathrm{i}}$ dans la rue . $_{\text {. }}$

- Anyi tụfụrụ $y a_{i}$ n'uzo . Nous $\boldsymbol{l}_{\boldsymbol{i}} \boldsymbol{y}_{\mathrm{j}}$ avons perdue $\mathrm{t}_{\mathrm{i}} \mathrm{t}_{\mathrm{j}}$

- O ziri $\boldsymbol{m}_{\boldsymbol{k}}$ ndi nyom $_{\boldsymbol{i}} \boldsymbol{o z} \boldsymbol{i}_{\boldsymbol{j}}$.

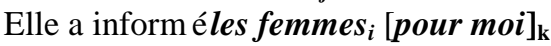

- O ziri $\boldsymbol{m}_{\boldsymbol{k}} \boldsymbol{h} \boldsymbol{a}_{\boldsymbol{i}} \boldsymbol{y} \boldsymbol{a}_{\boldsymbol{j}}$. Elle $\boldsymbol{m e}_{\boldsymbol{k}} \boldsymbol{l e s}_{\boldsymbol{i}}$ a informées $\mathrm{t}_{\mathrm{i}} \mathrm{t}_{\mathrm{k}}$.

In sentences (21) to (23), we observed that the double pronominalisation does feature in Igbo but does not involve all grammatical categories. The complements that are composed of prepositional phrases are not pronominalised as observed in sentence (22b) where the PP ' $n$ 'uzo' (which is the circumstantial complement of place) is not pronominalised. Moreover, when two NPs following each other are replaced by the same pronominal as in sentences (21a) and (21b), the process of pronominalisation is limited to just one of the NPs at a time to avoid ambiguity.

\section{Pronominalisation in the Imperative Structure}

In contrast to other types of sentences, the phenomenon of pronominalisation in the imperative sentence structure is limited to replacement in French as well as in Igbo as observed in sentences (24b), (25b) et (26b). However, transformational rule of movement still applies to the negative form of the imperative sentences in French as observed in sentence (26c).

- Zaa [ajuju ndi a $]_{\mathrm{i}}$ dum. Répondez [à toutes les questions $]_{\mathrm{i}}$.

- Zaa $\boldsymbol{h} \boldsymbol{a}_{\mathrm{i}} \mathrm{dum}$

- Répondez-y

- Sienu ji $i_{\text {. }}$ Préparez [de l'igname $]_{\mathrm{i}}$.

- Sienu $y a_{\mathrm{i}}$. Préparez-en

- Kpọo umuagbogho $\boldsymbol{k}_{\boldsymbol{k}}$ niile ! Appelez [toutes les demoiselles $]_{k}$ !

- Kpọo $\boldsymbol{h} \boldsymbol{a}_{\mathrm{k}}$ niile ! Appelez-les $\boldsymbol{s}_{\boldsymbol{k}}$ !

- Akpola $\boldsymbol{h a}_{\mathrm{k}}$ niile. Ne les $_{\mathrm{k}}$ appelez pas $\mathrm{t}_{\mathrm{k}}$ !

In the $2^{\text {nd }}$ person plural, the imperative sentence retains its subject pronoun ' $u n u$ ' in Igbo, but the first syllable ' $u$ ' of the subject pronoun is truncated before being attached to the verb in the sentence as a suffix. Example:
- Unu mechie ọnu. $\quad$ - Mechienu ọnụ!

Vous fermer (Présent) bouche. - Fermer (imp) vous bouche! Vous vous taisez. - Taisez-vous!

In Igbo, the morphemes of object pronominals also function as possessive pronouns when they are used alongside pronoun ' $n k e$ '. Examples:

- O nke m. - C'est le mien/la mienne.

- Nye ha nke ha. - Donne-les les leurs.

The morphemes of object pronominals are also used as possessive adjectives in Igbo. In this case as adjectives, they are preceded by the nouns they modify in the NP.

- Amaka, ọ bu nwa gị?

Amaka, elle est fille ta?

Amaka est-elle ta fille?

- Ụlo anyị dị nso.

Maison notre est près.

Notre maison est près.

The possessive adjective and the nouns they modify are in bold letters. In sentence (30a), we observed that subject pronoun ' $O$ ' is in apposition with the subject lexical NP 'Amaka' which it precedes. In fact, in Igbo, for pronominals, it is their syntactic function in the sentence that determines their form or grammatical category.

\section{CONCLUSION}

The phenomenon of pronominalisation as observed in this study does exist in Igbo; however the syntactic operation involved in it is limited to replacement and does not involve movement of pronominals as in the case of French. This is because pronominals in Igbo are not clitics as in the case of the French language rather they are, as discovered in this study autonomous elements of which their forms and grammatical categories are determined by their syntactic function in a sentence. Moreover in Igbo, the phenomenon of pronominalisation applies only to the NP syntactic category, while in French, pronominalisation involves basically the replacement of all syntactic categories be they grammatical or functional categories [NP, AdvP, PP, AdjP, $\mathrm{CP}$ or IP] as well as their movement. Another syntactic trait noted in Igbo in contrast to French is the absence of gender agreement between pronominals and their co-referrals (the NP they replace) in Igbo. However, person and number agreement exist between pronominals and their coreferential in Igbo. The limitation of the phenomenon of pronominalisation in Igbo to only replacement could constitute a syntactic problem to Igbo learners of French. We hope therefore, that this study has unravelled to a large extent the intricacies of the phenomenon of pronominalisation as it applies in French and in Igbo, thereby affording a better understanding of this syntactic operation in these two languages. However, it is important to point out that this study is by no means exhaustive; hence, further studies are encouraged on the subject of pronominalisation. 


\section{REFERENCES}

[1] M. A. Uwalaka, Igbo Grammar, Ibadan: The Pen Services, 1997, p. 1

[2] N. Emenanjo, "Central Igbo: An objective appraisal," in Igbo Language and Culture, F. C. Ogbalu and E. N. Emenanjo, Eds. Ibadan: OUP, 1978, vol. 1, pp. 114-137.

[3] O. C. Ihejirika, Igbo for Learners 1, Ibadan: Onigbonoje Press, 1997, pp. 1-2.

[4] J. Picoche and C. Marchello-Nizia, Histoire de la Langue Française. Paris: Nathan, 1991, pp. 11-38.

[5] C. Nique, Initiation Méthodique à la Grammaire Générative, Paris: Librairie Armand Colin, 1974, p. 76.

[6] N. Chomsky, Structures Syntaxiques, Paris: Seuil, 1969, p. 68.

[7] M. Oliveri, "Phénomène et Mécanisme de pronominalisation en français,’Ph.D. dissertation, p. 9, Univ. of Nice, Sophia Antipolis, 1994.

[8] E. Benveniste, Problèmes de Linguistique Générale 1, Paris: Edition Gallimard, 1966, p. 251.

[9] N. Emenanjo, Elements of Modern Igbo Grammar, Ibadan: OUP, 1978, pp. 60-61.

[10] B. M. Mbah and E. E. Mbah, Topics in Phonetics and Phonology: Contribution from Igbo. Nsukka: AP Express Publishers, 2000, pp. 82-83.

[11] B. M. Mbah, GB Syntax: A Minimalist Theory and Application to Igbo, Enugu: Catholic Institute for Development, Justice and Peace Press, 2006, p. 67.

[12] B. O. Oluikpe, English in Igboland: A Contrastive Study of English and Igbo Syntax, Onitsha: Africana Publishers Limited, 1978, p. 22.
[13] D. Ayi-Adzimah, "La maitrise sémantico-syntaxique de la pronominalisation des compléments d'objet indirect en contexte ghanéen," Ph.D. dissertation, pp. 72-73, Faculty of Humanities, Univ. of Strasbourg, 2010.

[14] J. Dubois and F. Dubois-Charlier, Éléments de Linguistique Française, Paris: Librairie Larousse, 1970, pp. 228-229.

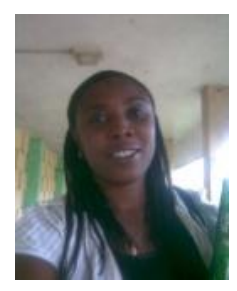

Ngozika Offor is a Nigerian. She was born in Takum, Taraba State, in 1978. She is a Igbo by tribe. Ngozika Offor holds a bachelor's degree in French from Nnamdi Azikiwe University, Awka, Anambra State, Nigeria in 2000; a postgraduate diploma in education from National Teachers' Institute, Kaduna, Nigeria in 2007 and also has a master degree in international affairs and diplomacy (MIAD) from Ahmadu Bello University, Zaria, Kaduna State in 2010. She is currently running a master's program in French in Ahmadu Bello University, Zaria, Kaduna State Nigeria.

She is a French teacher. Presently, she lectures in the Department of French, Federal College of Education, Kontagora, Niger State, Nigeria. She has also written some articles which include: "Une lecture postcoloniale d'Uwaoma et le beau monde," Northern Inter-University French Journal, vol. 3, no. 1, Sept. 2011; "Nigeria and Globalisation: The role of French language," Academic scholarship Journal, vol. 8, no. 1, April, 2014. Her research interest is in the area of language and comparative linguistics. 